Perić Tina

Mihanović Vice

Račić Nikola

http://dx.doi.org/10.21278/brod70305

ISSN 0007-215X

eISSN 1845-5859

\title{
EVALUATION MODEL OF MARINE POLLUTION BY WASTEWATER FROM CRUISE SHIPS
}

UDC 262.3:629.541.42:628.3

Original scientific paper

\begin{abstract}
Summary
In this paper, all factors that have an impact on marine pollution by sanitary wastewater from cruise ships were explored and analysed. A case study was done in which the movement of cruise ships in the Adriatic Sea was followed. Based on the results of that case study, a model of cruise ship traffic in the Adriatic Sea was developed, which, based on cruise ships itineraries in a certain period of time, gives retention times of ships in fourteen defined geographical areas of the Adriatic Sea. This model provides basic input parameters for the original evaluation model of marine pollution by wastewater from cruise ships, which is presented in this paper. By changing operation modes of the ship in different scenarios, evaluation model enables simulation of various scenarios in order to obtain the desired or expected load values of wastewater from cruise ships in fourteen defined geographical areas of the Adriatic Sea.
\end{abstract}

Key words: $\quad$ cruise ships; sanitary wastewater; marine pollution from ships

\section{Introduction}

Cruise ship traffic is a part of a shipping industry, which is growing constantly both in number of ships and their capacity. Growth of cruise ship tourism in general is impressive demand for cruising increased almost 50\% in five-year period from 2000-2005 and then again by $50 \%$ in nine-year period from 2005 to 2014 [1] and at last $20.5 \%$ in the last five years [2]. Currently, there are 275 large cruise ships (capacity more than 500 passengers) [3]. Cruise tourism represents a high environmental impact activity with a global presence and rapid growth. It raises concerns due to its tendency of being environmental unsustainable [4]. Cruise ships represent less than $1 \%$ of the global merchant fleet yet it has been estimated that they are responsible for $25 \%$ of all waste generated by merchant vessels [5].

In 2018, 75 cruise vessels arrived in Croatian seaports and they realised 693 journeys. More than one million passengers were on board and they stayed for 1421 days in Croatia, that is, 2.1 days on average [6].

Main difference between cruise ships and all other merchant ships is in number of persons they carry. That raised question about discharge of sanitary wastewater from cruise ships and potential pollution from it. 
Sanitary wastewater (WW) in order to increase efficiency and disposal is further divided into black water (BW) and grey water $(\mathrm{GW})$. Black water is discharge from all types of toilets and urinals and Annex IV of MARPOL Convention regulates it. Black water may host many pathogens of concern to human health, including Salmonella, Shigella, hepatitis A and E, and gastro-intestinal viruses. Sewage contamination in swimming areas and shellfish beds pose potential risks to human health and the environment by increasing the rate of waterborne illnesses [7].

Annex IV of MARPOL Convention is governing standards for the discharge of sanitary wastewater according to three areas of navigation [8]. For each of these zones Annex IV proscribes standards of quality for discharged wastewater. However, problem lays in the fact that international legislation treats merchant ships with usually 30 persons on board same as cruise ships where the number of persons on board may exceed 8,000 people.

Grey water contains water from sinks, baths, showers, washing machines, saunas, swimming pools, sinks and water generated from washing ship's surface and it is not recognized as pollutant by IMO so it can be discharged untreated into the sea. Grey water contains an array of pollutants from the highly acid (bleach, strong acids from some cleaning products giving water low $\mathrm{pH}$ ) or strong alkalis (including many detergents, phosphates, whiteners, and foaming agents giving water high $\mathrm{pH}$ ), to oil and grease, suspended solids and organic particles. In addition, degreasers found in washing up liquids and soaps strip the natural oils from fish gills making it difficult for them to breathe. In addition, researches have proven that untreated grey water contains bacteria and suspended solids concentrations equal to or exceeding black water [9].

Environmental impacts from ocean and coastal tourism include environmental degradation and pollution, destruction of habitat and ecosystem damage, and coastal pollution (wastewater, sewage and air). Such impacts have been documented in Australia, Caribbean and South Pacific Island nations, Europe, Central and South America and Polar Regions [10].

Since Adriatic Sea is semi-closed type of sea with great dependence of its countries on tourism, concern arises about pollution of the Adriatic from cruise ship sanitary water. Data about quantity and quality of discharged wastewater could not be found, therefore, a model that could evaluate this kind of pollution in the Adriatic Sea was developed.

Firstly, a case study was made in which each cruise ship was followed during its stay in the Adriatic. For each cruise ship, relevant data was noted: routes between the ports, time of entrance and exit from the Adriatic Sea and time of entrance and exit from four relevant navigation zones:

- ZONE 1: port/anchorage where ZONE 1a is Croatian port/anchorage, and ZONE 1b is foreign port/anchorage,

- ZONE 2: sea area to $3 \mathrm{M}$ from the nearest land,

- ZONE 3: sea area from 3 to $12 \mathrm{M}$ from the nearest land

- ZONE 4: sea area beyond 12 M from the nearest land.

After that, an evaluation model of marine pollution by sanitary wastewater from cruise ships was developed as a part of doctoral dissertation [11], which will be presented in following chapters.

The expected contribution to science in theoretical sense is proposed evaluation model that includes and recognizes all the factors that affect quantity and quality of discharged sanitary wastewater from cruise ships in the Adriatic Sea using scientific theoretical premises and scientific methods in collecting and data processing. 


\section{Research analysis}

To create the evaluation model of marine pollution by wastewater from a cruise ship, three interdependent categories of factors affecting the pollution of the marine environment were used. These categories are:

- Movement of cruise ships in the Adriatic Sea,

- Quantity of discharged wastewater and

- Quality of discharged wastewater.

\subsection{Cruise ship traffic in the Adriatic Sea}

For the first category, movement of cruise ships, model of cruise ship traffic in the Adriatic Sea was developed [12], which, based on input parameters - cruise ships itineraries in a certain period of time, gives output parameters - retention times of ships in geographical areas of the Adriatic Sea. For purposes of this research, Adriatic Sea was divided on four zones of navigation and fourteen geographical zones (gz) shown in Fig. 1.

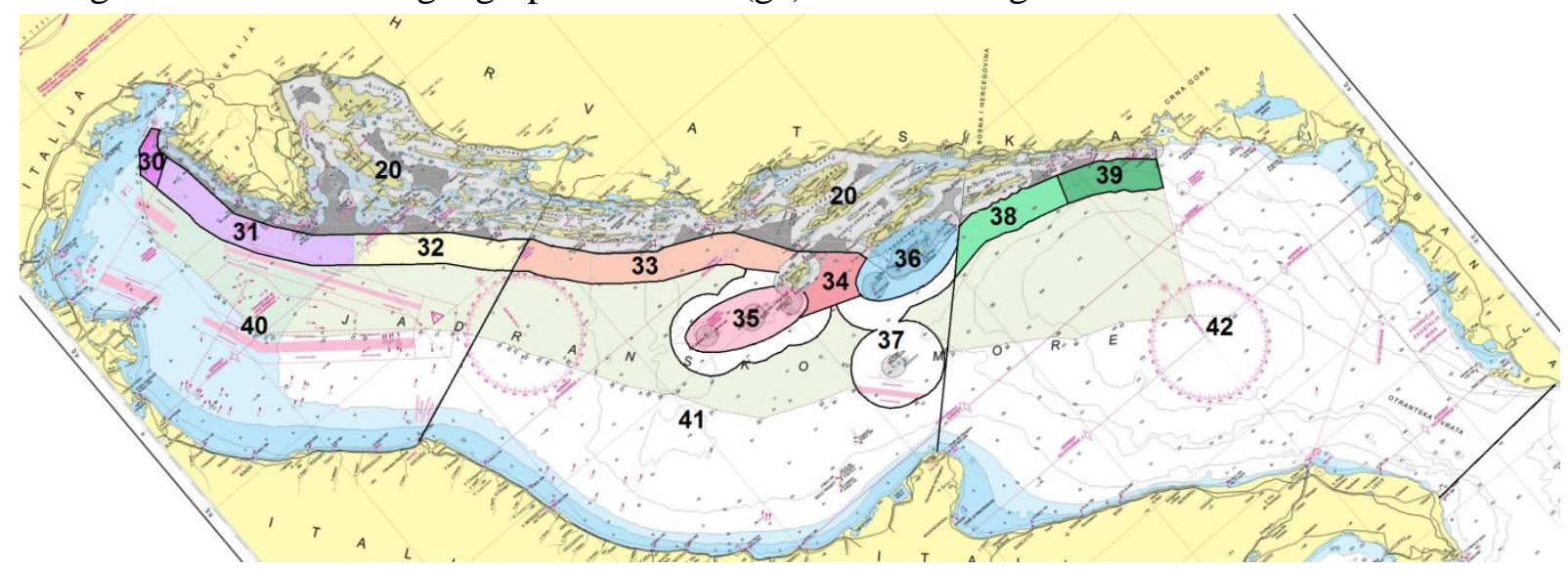

Fig. 1 Geographical zones of navigation in the Adriatic Sea

\subsection{Quantity of discharged wastewater}

Quantity of discharged wastewater depends on the following factors: capacity of ship (number of passengers and crew) and working mode of the ship.

Capacity of the ship allows us to calculate total number of persons onboard in a certain time period. Taking into account results of previous studies, in which is concluded that one person onboard a cruise ship produces 31.8 1/day of black water and 253 1/day of grey water [7], it is possible to calculate generated black and grey water onboard the ship in specified time period.

Ship in navigation uses four working modes regarding discharge of sanitary wastewater:

- MODE 1: Wastewater is not discharged, it is retained in ship's holding tanks;

- MODE 2: Wastewater is discharged after treatment with advanced wastewater treatment systems installed on ship;

- MODE 2*: Wastewater is discharged after treatment with advanced wastewater treatment (AWT) systems installed on ship but without last treatment step disinfection;

- MODE 3: Wastewater is discharged partially treated (comminuted and disinfected) with Marine sanitation device (MSD);

- MODE 4: Wastewater is discharged untreated directly to the sea. 
Working mode of the ship is in direct correlation with the type of treatment system on board the ship because system performances must meet legal regulations for each zone of navigation.

\subsection{Quality of discharged wastewater}

The quality of sanitary wastewater is determined by the amount of certain substances and energy that is contained in wastewater. It should be noted that, depending on their source on ship, all wastewater contains various amounts and concentrations of waste products that are characterized with respect to their physical, chemical and microbiological properties [7, 13]. There are a great number of indicators, but with their impact on the marine environment and human health following wastewater, quality factors are distinguished:

- feacal or thermotolerant coliforms, FK,

- total suspended solids, TSS,

- 5-day biochemical oxygen demand, $\mathrm{BOD}_{5}$ and chemical oxygen demand, COD,

- $\mathrm{pH}$ value,

- chlorine residual,

- total nitrogen and

- total phosphorus.

A comparison of quality of discharged sanitary wastewater from the treatment system considering quality criteria and minimum requirements of Annex IV of MARPOL Convention is shown in Table 1.

Table 1 Comparison of quality of discharged sanitary wastewater from the treatment system considering quality criteria and minimum requirements of MARPOL Convention [7, 8, 14, 15]

\begin{tabular}{|c|c|c|c|c|c|c|}
\hline \multirow{3}{*}{$\begin{array}{l}\text { Discharge } \\
\text { quality for }\end{array}$} & \multirow{3}{*}{$\begin{array}{c}\text { Type of } \\
\text { wastewater }\end{array}$} & \multirow{3}{*}{$\begin{array}{l}\text { operational mode/ } \\
\text { zone }\end{array}$} & \multicolumn{4}{|c|}{ Discharged wastewater quality factors } \\
\hline & & & $\begin{array}{l}\text { Feacal } \\
\text { coliform }\end{array}$ & $\mathrm{BOD}_{5}$ & TSS & $\begin{array}{l}\text { Chlorine } \\
\text { residual }\end{array}$ \\
\hline & & & $\mathrm{FK} / 100 \mathrm{ml}$ & $\mathrm{mg} / \mathrm{l}$ & $\mathrm{mg} / \mathrm{l}$ & $\mu \mathrm{g} / 1$ \\
\hline \multirow{3}{*}{ MSD } & \multirow{2}{*}{ black water } & MODE 3 & $2,040,000$ & 133 & 627 & 1,070 \\
\hline & & MODE 4 & $636,000,000$ & 526 & 704 & 372 \\
\hline & gray water & MODE 4 & $36,000,000$ & 1,140 & 704 & 372 \\
\hline \multirow{3}{*}{$\begin{array}{l}\text { AWT } \\
\text { system }\end{array}$} & \multirow{3}{*}{$\begin{array}{l}\text { black and } \\
\text { gray water }\end{array}$} & MODE 2 & 14.5 & 7.99 & 4.49 & 338 \\
\hline & & MODE $2 *$ & 25,500 & 7.99 & 4.49 & 338 \\
\hline & & MODE 4 & $103,000,000$ & 526 & 704 & 372 \\
\hline \multirow{4}{*}{$\begin{array}{c}\text { MARPOL } \\
\text { Annex IV } \\
\text { zones }\end{array}$} & black water & zone to $3 \mathrm{M}$ old $^{1}$ & 250 & 50 & 100 & 500 \\
\hline & black water & zone to $3 \mathrm{M}$ & 100 & $25 \cdot Q_{i} / Q_{e}{ }^{2}$ & $35 \cdot Q_{i} / Q_{e}{ }^{2}$ & 500 \\
\hline & black water & zone $3-12 \mathrm{M}$ & \multicolumn{4}{|c|}{ Discharge of comminuted and disinfected black water } \\
\hline & black water & zone outside $12 \mathrm{M}$ & \multicolumn{4}{|c|}{$\begin{array}{l}\text { Discharge of untreated black water at a moderate rate when the ship } \\
\text { is en route and proceeding at not less than } 4 \text { knots. }\end{array}$} \\
\hline
\end{tabular}

Table 1 shows that treated black water from MSD has about 2 million faecal coliform while treated sanitary wastewater from AWT plant has 14.5 faecal coliforms in $100 \mathrm{ml}$ of discharged wastewater. The values of other quality factors of sanitary wastewater are also several times higher at the exit of the MSD compared to the output from the AWT system. It 
can be concluded that there is great disproportion in quality of discharged wastewater directly related to the type of wastewater treatment system installed on cruise ships. Defined quality can be even worse because of insufficient familiarisation of engineering crew with complex wastewater treatment plants unique for cruise ships [16].

\section{Model}

Evaluation model of marine pollution by wastewater from cruise ships enables us to calculate quantity and quality of discharged wastewater in specified geographic areas of the Adriatic Sea considering selected operational modes in those areas. Calculation steps are shown in flow chart in Fig. 2.

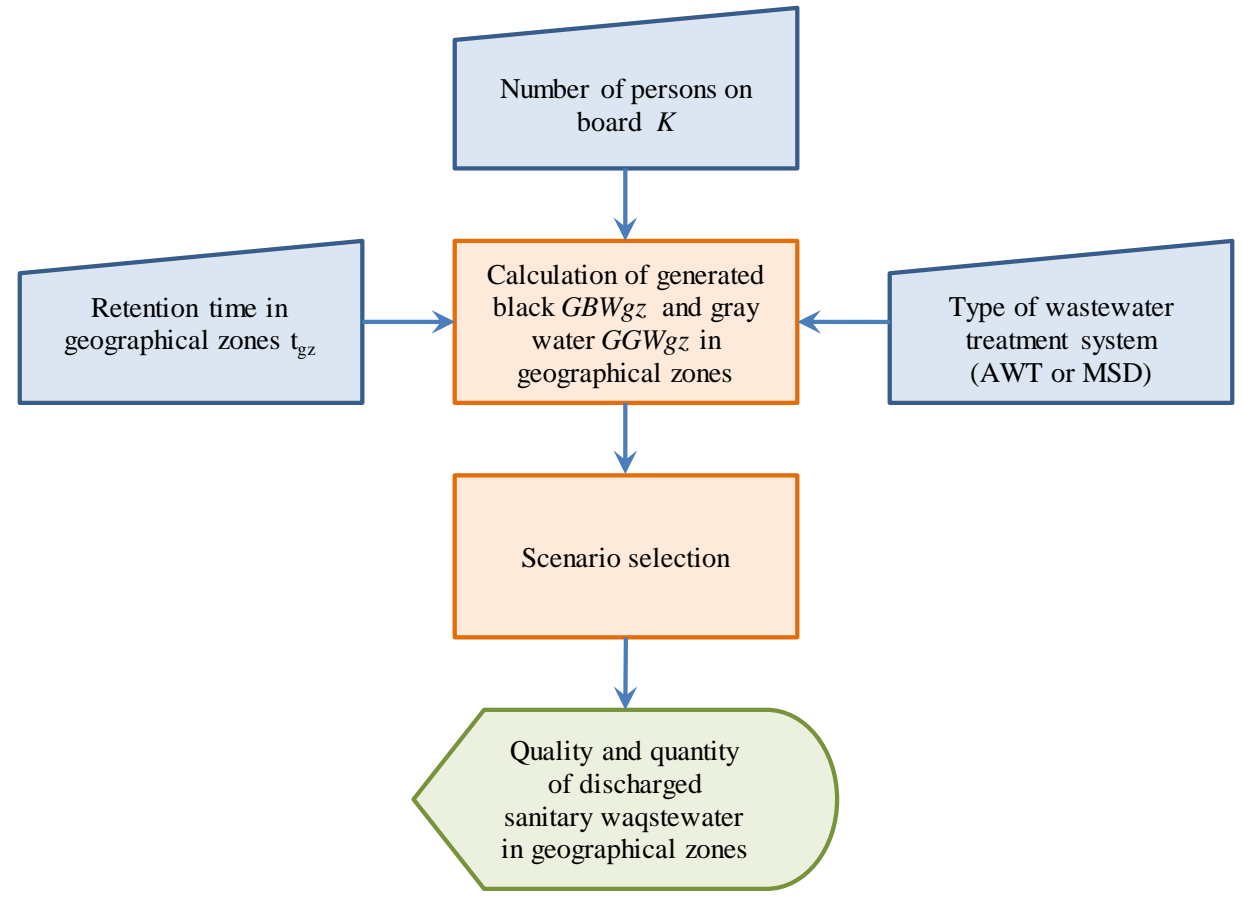

Fig. 2 Quality and quantity of discharged wastewater calculation flow chart

The model consists of the mandatory input parameters without which calculation cannot be performed:

- name of the ship with number of persons onboard,

- retention time in geographic zones $t_{g z}$,

- type of wastewater treatment system (AWT or MSD),

- selection of operational modes in each navigation zone.

By knowing the retention time in navigation zones for a particular route $t_{g z}$ and the number of persons on board a cruise ship i.e. its capacity $K$ it is possible to calculate quantity of generated black and gray wastewater [12]:

$$
\begin{aligned}
& G B W=\frac{K \cdot F_{B W} \cdot t}{1000}\left[\mathrm{~m}^{3}\right] \\
& G G W=\frac{K \cdot F_{G W} \cdot t}{1000}\left[\mathrm{~m}^{3}\right]
\end{aligned}
$$


where:

$G B W$ is quantity of generated black water,

$G G W$ is quantity of generated gray water,

$K$ is average number of persons on the ship,

$F_{B W}$ is black water constant and it is $1.325 \mathrm{l} /$ person/h,

$F_{G W}$ is gray water constant and it is $10.54 \mathrm{l} / \mathrm{person} / \mathrm{h}$,

$t$ is retention time in sea area $[\mathrm{h}]$.

Knowledge of the type of wastewater treatment system installed on the ship enables us to recognize the quality of discharged sanitary wastewater according to operational mode of the ship (Table 1). Selection of operational modes in Annex IV navigation zones is directly depended on the system type on the ship. Fig. 3 shows all possible combinations of operational modes in navigation for AWT and MSD ships, where the minimum operational mode that can be selected is one legally allowed by Annex IV of MARPOL Convention.

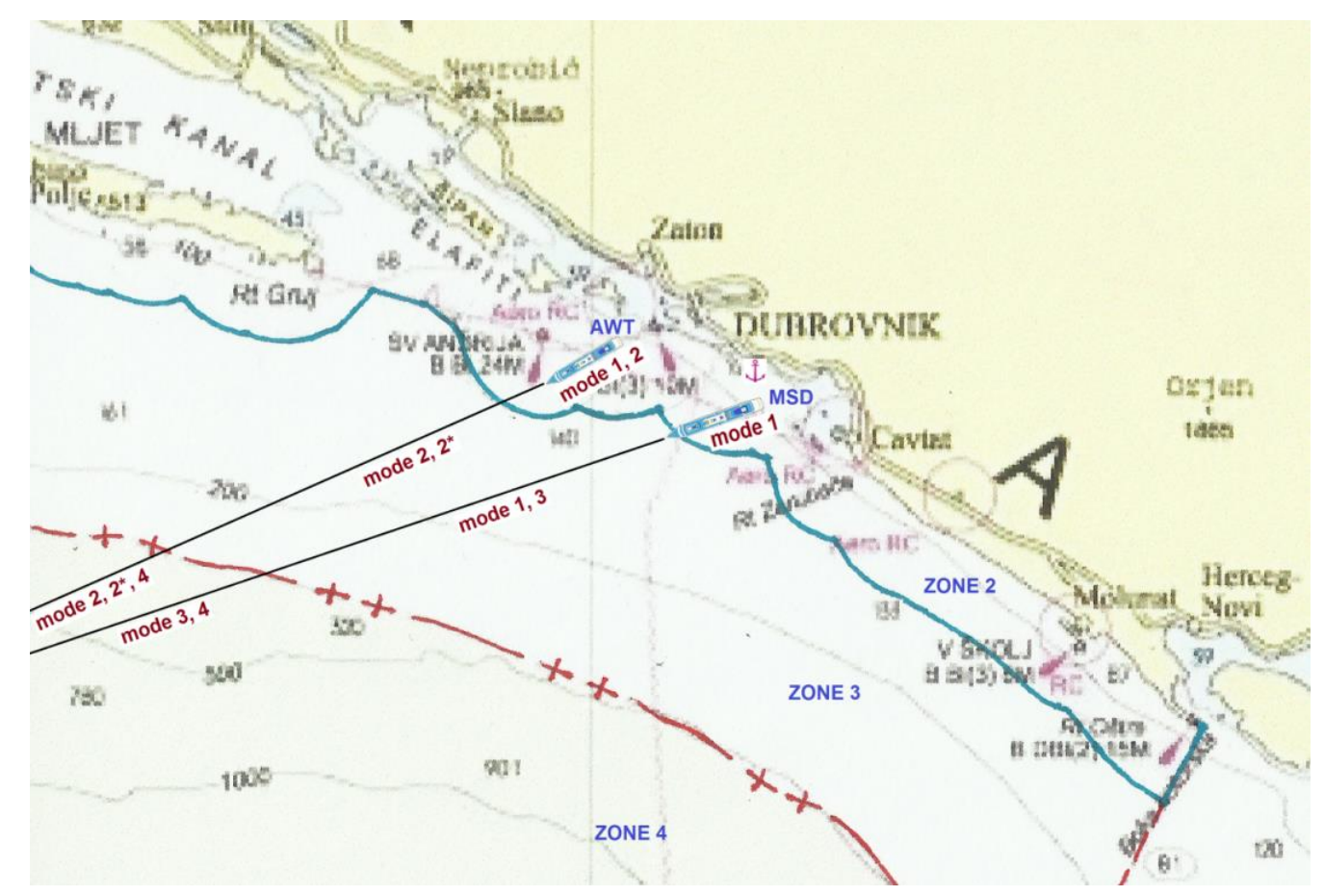

Fig. 3 Possible combinations of treatment system working modes according to MARPOL Convention

Operational mode for black and gray water is separately chosen in MSD, while the AWT system collects and processes black and gray water together so the selection of operational mode applies to both. By changing operational modes of the ship in different scenarios evaluation model of marine pollution allows simulation of different scenarios in order to obtain the desired or expected values of specific sea area load with wastewater from cruise ships. That enables the evaluation of current legislation and identification of critical areas of the sea regarding wastewater pollution from cruise ships. As seen in Fig. 3, there are many possible scenarios; however, the operation logic is the same.

In zones selected for mode 1 generated wastewater is collected in holding tanks. Rate of discharge from holding tanks is an optional input parameter. The ship at sea navigates through specified geographic areas in the order defined by the route it is on and retention time $t_{g z}$ in each of these areas provided by the cruise traffic model. Once the ship enters in the first zone in which discharge is allowed within the selected scenario, discharge from holding tanks can begin following one of these principles: 
a) If the rate of discharge $\left(\mathrm{m}^{3} / \mathrm{h}\right)$ is defined, holding tanks will be discharged in zones selected for discharging at that rate until they are empty.

b) If the rate of discharge is not defined, the tanks will be discharged continuously in zones in which discharge is allowed with intention of emptying them until the next port. Discharge will be carried at average discharge rate, which is obtained as the ratio of the quantity of wastewater in holding tanks $\left(\mathrm{m}^{3}\right)$ and retention time $(\mathrm{h})$ in zones of allowed discharge on the route. If ship does not enter any zones of allowed discharge by the selected scenario on a route (e.g. the whole voyage takes place in zone 2 ) than the quantity of generated wastewater on this route is accumulated and transferred for discharge to the next route.

The scenario that strictly follows the rules of MARPOL Annex IV is called Scenario 1. Scenario 1 for MSD is shown in Fig. 4 and for AWT systems in Fig. 5.

Ships with MSD separately collect black and gray water. Only black water is processed while the gray is discharged without processing. MARPOL Convention does not recognize gray water as a pollutant and there are no regulations for the discharge of the same. Therefore, scenario 1 of MSD stipulates detention of gray water in holding tanks only while the ship is in port and discharge in all other zones. Black water is retained in holding tanks in zones 1 and 2 while it is discharged treated in zone 3 and untreated in zone 4. Discharge from holding tanks starts in zone 3 as shown in flow diagram in Fig. 4.

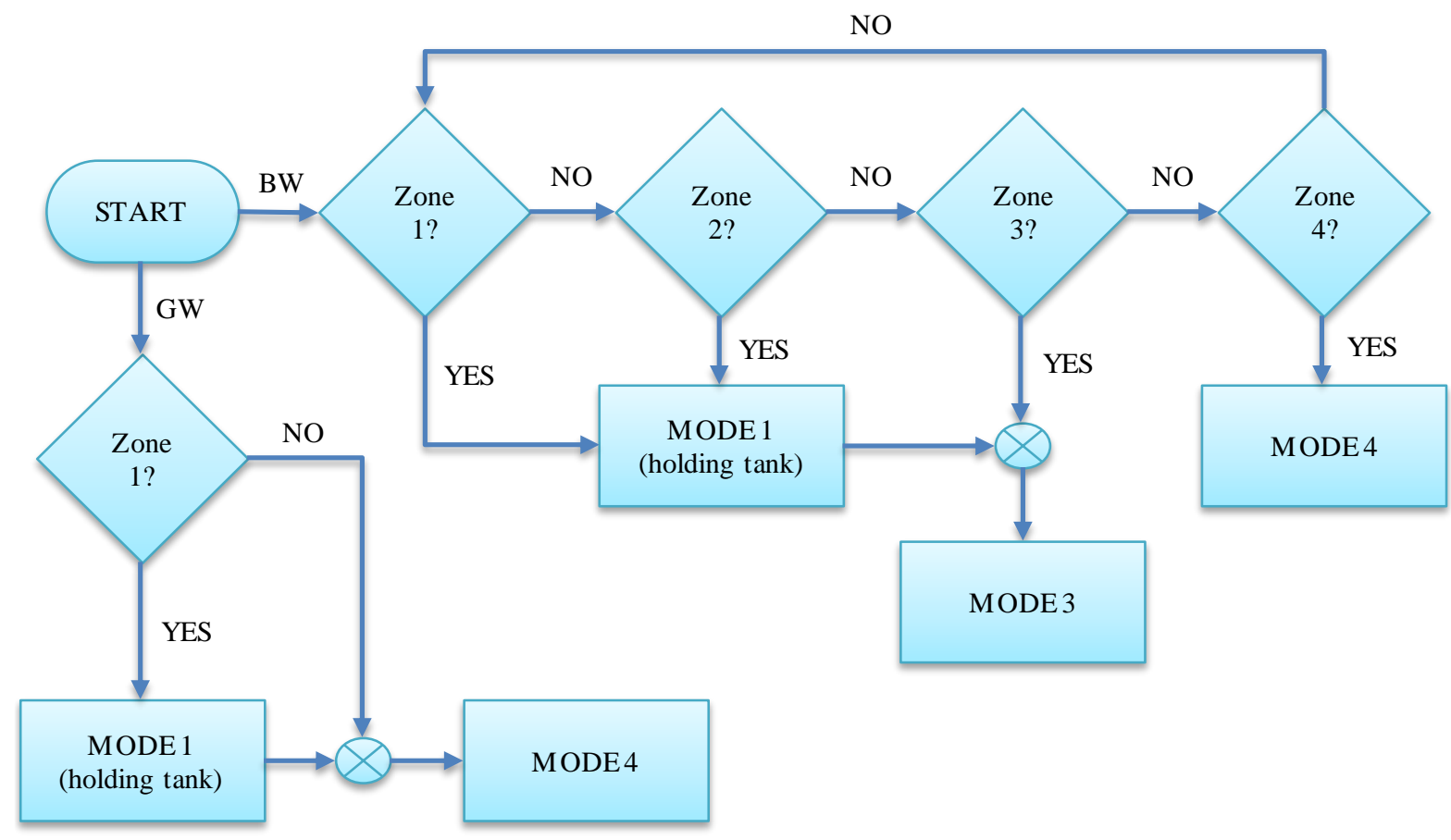

Fig. 4 Scenario 1 flow chart for MSD [11]

AWT system handles both black and gray water so in this case regulations for black water are applied also to the gray water because it is mixed with black. According to Annex IV of MARPOL Convention ships with AWT systems which have received Certificate of Type Approval by the Administration can continuously discharge sanitary wastewater processed with AWT system (mode 2). However, in zone 3 wastewater can be discharged partially treated (without UV disinfection - mode $2^{*}$ ), and in zone 4 untreated (mode 4 ) as shown in the flow diagram in Fig. 5. 


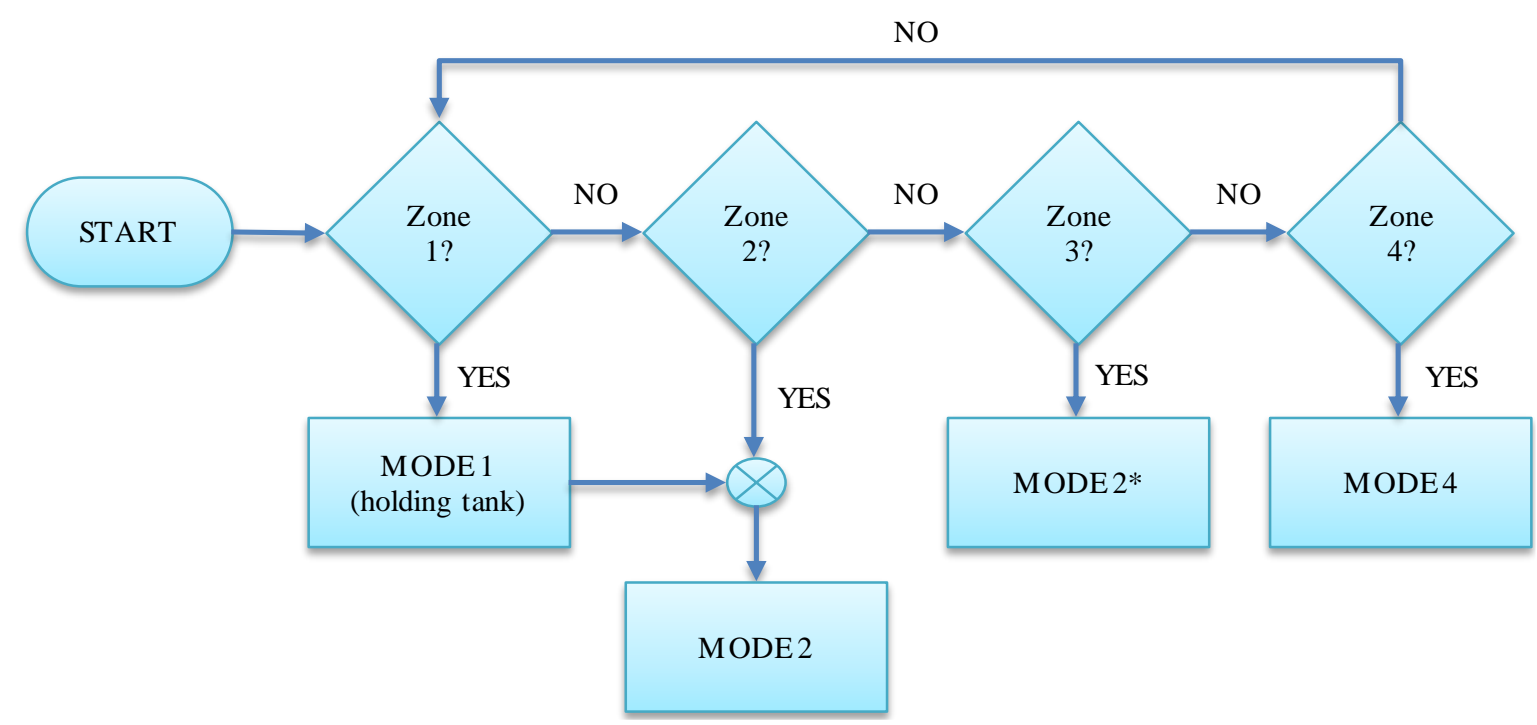

Fig. 5 Scenario 1 flow chart for AWT system [11]

\section{Simulation with model}

Through the presented model it is possible to evaluate marine pollution by wastewater from cruise ships. According to the cruise traffic model [12], in the year of case study, cruise ships have spent: $1454 \mathrm{~h}$ in zone 2 which is approximately 61 days; $5087 \mathrm{~h}$ in zone 3, approximately 212 days and $19351 \mathrm{~h}$ in zone 4, approximately 806 days. It is important to note that zone 4 includes the entire Adriatic Sea outside the territorial sea of the Republic of Croatia which means that it also includes territorial waters of Italy, Slovenia, Montenegro and Albania. Since the focus of the research was pollution of the Croatian part of the Adriatic Sea retention times in zones 2 and 3 of these countries were included in zone 4 of the model.

Retention times in geographical areas $t_{g z}$ provided from cruise traffic model on basis of cruise ship itineraries together with the average capacity of the ships ${ }^{1}$ enables us to calculate generated black $\left(\mathrm{GBW}_{\mathrm{gz}}\right)$ and gray water $\left(\mathrm{GGW}_{\mathrm{gz}}\right)$ in each geographical area, using formula (1) and (2), which is presented in Table 2. This distribution of generated black and gray water presents entry parameters for simulation of different scenarios regarding selection of operational modes in evaluation model.

For purposes of this case study it is assumed that cruise ships do not discharged wastewater during their stay in the harbor/anchorage. Since only AWT systems can discharge treated wastewater in zone 2, part of the wastewater generated in zone 2 will be discharged in the first zone 3 that follows. In addition, the amount of wastewater generated in the Croatian port will be discharged in zone 2 (AWT systems) or in zone 3 (MSD systems), and generated wastewater in a foreign port will be discharged in the corresponding zone 4. Gray water of ships with MSD is discharged untreated always, except in the port when it is stored in holding tanks.

\footnotetext{
${ }^{1}$ Average capacity of ships in this case study is calculated in respect of retention time of each ship in the Adriatic Sea to their capacity and it is 2909 persons.
} 
Table 2 Distribution of retention time and generated sanitary wastewater in geographical zones of the Adriatic Sea [11]

\begin{tabular}{|c|c|c|c|c|c|c|c|}
\hline \multicolumn{2}{|c|}{$\begin{array}{c}\text { Geographic zone of the } \\
\text { Adriatic }\end{array}$} & \multicolumn{2}{|c|}{$\begin{array}{c}\text { Retention time in zone } \\
{[\mathrm{h}]}\end{array}$} & \multicolumn{2}{|c|}{$\begin{array}{c}\text { Generated black water - } \\
\text { GBW }\left[\mathrm{m}^{3}\right]\end{array}$} & \multicolumn{2}{|c|}{$\begin{array}{l}\text { Generated gray water - } \\
\text { GGW }\left[\mathbf{m}^{3}\right]\end{array}$} \\
\hline \multirow{2}{*}{ ZONE 1} & Croatian port & $t_{10}$ & 5208 & $G B W_{10}$ & 20064 & $G G W_{10}$ & 159672 \\
\hline & foreign port & $t_{11}$ & 1183 & $G B W_{11}$ & 45792 & $G G W_{11}$ & 364344 \\
\hline ZONE 2 & zone 2 & $t_{20}$ & 1454 & $G B W_{20}$ & 5604 & $G G W_{20}$ & 44582 \\
\hline \multirow{10}{*}{ ZONE 3} & Istra north & $t_{30}$ & 82 & $G B W_{30}$ & 315 & $G G W_{30}$ & 2508 \\
\hline & Istra west & $t_{31}$ & 598 & $G B W_{31}$ & 2306 & $G G W_{31}$ & 18346 \\
\hline & Zadar - Unije & $t_{32}$ & 138 & $G B W_{32}$ & 532 & $G G W_{32}$ & 4232 \\
\hline & Šolta - Kornati & $t_{33}$ & 425 & $G B W_{33}$ & 1640 & $G G W_{33}$ & 13045 \\
\hline & Vis - Lastovo & $t_{34}$ & 397 & $G B W_{34}$ & 1530 & $G G W_{34}$ & 12168 \\
\hline & Jabuka - Biševo & $t_{35}$ & 492 & $G B W_{35}$ & 1896 & $G G W_{35}$ & 15084 \\
\hline & Lastovo & $t_{36}$ & 702 & $G B W_{36}$ & 2704 & $G G W_{36}$ & 21511 \\
\hline & marginal sea & $t_{37}$ & 954 & $G B W_{37}$ & 3677 & $G G W_{37}$ & 29246 \\
\hline & Mljet & $t 38$ & 697 & $G B W_{38}$ & 2685 & $G G W_{38}$ & 21361 \\
\hline & Dubrovnik - Kotor & $t_{39}$ & 602 & $G B W_{39}$ & 2320 & $G G W_{39}$ & 18458 \\
\hline \multirow{3}{*}{ ZONE 4} & north Adriatic & $t_{40}$ & 6628 & $G B W_{40}$ & 25548 & $G G W_{40}$ & 203226 \\
\hline & middle Adriatic & $t_{41}$ & 3402 & $G B W_{41}$ & 13112 & $G G W_{41}$ & 104303 \\
\hline & south Adriatic & $t_{42}$ & 93201 & $G B W_{42}$ & 35926 & $G G W_{42}$ & 285779 \\
\hline
\end{tabular}

Current world ratio regarding wastewater treatment system on large cruise ships is: $55 \%$ of ships with AWT systems and $45 \%$ of ships with MSD. However, in the year of the case study this ratio in Adriatic Sea was following: $52.4 \%$ of total number of cruise ships that entered Adriatic Sea had MSD. If we also take into account number of persons onboard we get this result: $52.7 \%$ of wastewater is processed on ships with AWT systems and $47.3 \%$ of wastewater is processed on ships with MSD systems. Guided by this ratio, the approximate quantity and quality of discharged wastewater in each geographical area in the case study year can be calculated as shown in Table 3. For the quality of discharged wastewater, it was assumed that ships follow the regulations of MARPOL Annex IV.

Summing quality of discharged wastewater $\left(\mathrm{DW}_{\mathrm{gz}}\right)$ from AWT and MSD results in total load of geographical areas in a year of research, graphically shown in Fig. 6. It should be noted that all calculations used the average retention times on each route, average capacity of ships and therefore results may vary from the actual values of pollution. However, the results are sufficiently accurate for general picture of pollution of the marine environment in the Adriatic Sea. Accurate results can be obtained using Kruzeri, software developed for easier calculations from mentioned models. Software uses accurate information for each cruise ship: capacity of the ship, the time of navigation on routes regarding ships itinerary and exact treatment system that is installed on the ship. 
Table 3 Distribution of estimated quantity and quality of discharged black (DBW $\left.\mathrm{gz}_{\mathrm{gz}}\right)$ and gray water $\left(\mathrm{DGW}_{\mathrm{gz}}\right)$ from cruise ships to the geographical zones of navigation in the one-year case study

\begin{tabular}{|c|c|c|c|c|c|c|c|c|c|c|c|c|c|c|}
\hline \multicolumn{15}{|c|}{ AWT } \\
\hline \multirow{2}{*}{\multicolumn{2}{|c|}{$\begin{array}{c}\text { Geographic zone of the } \\
\text { Adriatic }\end{array}$}} & \multicolumn{4}{|c|}{ Quantity of discharged wastewater } & \multirow{2}{*}{$\begin{array}{c}\text { Operational } \\
\text { mode for } \\
\text { wastewater }\end{array}$} & \multicolumn{4}{|c|}{$\begin{array}{l}\text { Quality factors of discharged } \\
\text { wastewater }\end{array}$} & \multicolumn{4}{|c|}{ Quality of discharged wastewater } \\
\hline & & \multicolumn{2}{|c|}{ Black water $\left[\mathbf{m}^{3}\right]$} & \multicolumn{2}{|c|}{ Gray water $\left[\mathrm{m}^{3}\right]$} & & $\mid \begin{array}{c}\text { FK } \\
\text { [in } 100 \mathrm{ml}]\end{array}$ & $\begin{array}{l}\text { BOD }_{5} \\
{[\mathrm{mg} / \mathrm{ll}]}\end{array}$ & $\begin{array}{c}\text { TSS } \\
{[\mathrm{mg} / \mathrm{ll}]}\end{array}$ & $\begin{array}{c}\text { Chlorine } \\
{[\mu \mathrm{g} / \mathrm{l}]}\end{array}$ & FK $\left(* 10^{9}\right)$ & $\begin{array}{l}\mathrm{BOD}_{5} \\
{[\mathrm{mg} / \mathrm{l}]}\end{array}$ & $\begin{array}{l}\text { TSS } \\
{[\mathrm{kg}]}\end{array}$ & $\begin{array}{c}\text { Chlorine } \\
{[\mathrm{g}]}\end{array}$ \\
\hline \multirow{2}{*}{ ZONE 1} & Croatian port & $D B W_{10}$ & 0 & $D G W_{10}$ & 0 & \multirow{2}{*}{ MODE 1} & \multirow{2}{*}{ I } & \multirow{2}{*}{ / } & \multirow{2}{*}{ / } & \multirow{2}{*}{ / } & 1 & 1 & I & l \\
\hline & foreign port & $D B W_{I I}$ & 0 & $D G W_{11}$ & 0 & & & & & & I & 1 & I & I \\
\hline ZONE 2 & zone 2 & $D B W_{20}$ & 13527 & $D G W_{20}$ & 107642 & MODE 2 & 14,5 & 7,99 & 4,49 & 338 & 18 & 968 & 544 & 40955 \\
\hline \multirow{10}{*}{ ZONE 3} & Istra north & $D B W_{30}$ & 166 & $D G W_{30}$ & 1322 & \multirow{10}{*}{ MODE 2* } & \multirow{10}{*}{25500} & \multirow{10}{*}{7,99} & \multirow{10}{*}{4,49} & \multirow{10}{*}{338} & 379 & 11 & 7 & 503 \\
\hline & Istra west & $D B W_{31}$ & 1215 & $D G W_{31}$ & 9668 & & & & & & 2775 & 87 & 49 & 3679 \\
\hline & Zadar - Unije & $D B W_{32}$ & 280 & $D G W_{32}$ & 2230 & & & & & & 640 & 20 & 11 & 848 \\
\hline & Šolta - Kornati & $D B W_{33}$ & 864 & $D G W_{33}$ & 6875 & & & & & & 1973 & 62 & 35 & 2616 \\
\hline & Vis - Lastovo & $D B W_{34}$ & 806 & $D G W_{34}$ & 6413 & & & & & & 1841 & 58 & 32 & 2440 \\
\hline & Jabuka - Biševo & $D B W_{35}$ & 999 & $D G W_{35}$ & 7949 & & & & & & 2282 & 71 & 40 & 3025 \\
\hline & Lastovo & $D B W_{36}$ & 1425 & $D G W_{36}$ & 11336 & & & & & & 3254 & 102 & 57 & 4313 \\
\hline & marginal sea & $D B W_{37}$ & 1938 & $D G W_{37}$ & 15413 & & & & & & 4424 & 139 & 78 & 5864 \\
\hline & Mljet & $D B W_{38}$ & 1415 & $D G W_{38}$ & 11257 & & & & & & 3231 & 101 & 57 & 4283 \\
\hline & Dubrovnik - Kotor & $D B W_{39}$ & 2584 & $D G W_{39}$ & 20557 & & & & & & 5901 & 185 & 104 & 7821 \\
\hline \multirow{3}{*}{ ZONE 4} & north Adriatic & $D B W_{40}$ & 27641 & $D G W_{40}$ & 219906 & \multirow{3}{*}{ MODE 4} & \multirow{3}{*}{103 mil. } & & & & 254973472 & 130210 & 174273 & 92088 \\
\hline & middle Adriatic & $D B W_{41}$ & 6910 & $D G W_{41}$ & 54968 & & & 526 & 704 & 372 & \begin{tabular}{|l|}
63734108 \\
\end{tabular} & 32548 & 43562 & 23019 \\
\hline & south Adriatic & $D B W_{42}$ & 27526 & $D G W_{42}$ & 218980 & & & & & & 253901348 & 129662 & 173540 & 91700 \\
\hline & & & & & & & MSD & & & & & & & \\
\hline Geogr & aphic zone of the & Quantity & of disch & arged wa & stewater & $\begin{array}{l}\text { Operational } \\
\text { mode for }\end{array}$ & Quality & $\begin{array}{l}\text { factors } \\
\text { lack/gra }\end{array}$ & $\begin{array}{l}\text { of discha } \\
\text { y water }\end{array}$ & arged & Quality & of discha & ged waste & water \\
\hline & Adriatic & Black wa & ter $\left[\mathrm{m}^{3}\right]$ & Gray wa & $\operatorname{ter}\left[\mathbf{m}^{3}\right]$ & $\begin{array}{c}\text { black/gray } \\
\text { water }\end{array}$ & $\begin{array}{c}\text { FK } \\
\text { [in } 100 \mathrm{ml}]\end{array}$ & $\begin{array}{l}\text { BOD }_{5} \\
{[\mathrm{mg} / \mathrm{ll}]}\end{array}$ & $\begin{array}{c}\text { TSS } \\
{[\mathrm{mg} / \mathrm{l}]}\end{array}$ & $\begin{array}{c}\text { Chlorine } \\
{[\mu \mathrm{g} / \mathrm{l}]}\end{array}$ & FK $\left(* 10^{9}\right)$ & $\begin{array}{l}\text { BOD }_{5} \\
{[\mathrm{mg} / \mathrm{l}]}\end{array}$ & $\begin{array}{l}\text { TSS } \\
{[\mathrm{kg}]}\end{array}$ & $\begin{array}{c}\text { Chlorine } \\
{[\mathrm{g}]}\end{array}$ \\
\hline ZONE 1 & Croatian port & $D B W_{10}$ & 0 & $D G W_{10}$ & 0 & MODE 1 & 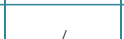 & 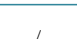 & 1 & 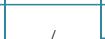 & I & I & I & I \\
\hline ZUNE 1 & foreign port & $D B W_{I I}$ & 0 & $D G W_{11}$ & 0 & MODE 1 & 1 & 1 & 1 & 1 & 1 & 1 & 1 & 1 \\
\hline ZONE 2 & zone 2 & $D B W_{20}$ & 0 & $D G W_{20}$ & 96612 & MODE $1 / 4$ & $136 \mathrm{mil}$. & $/ 1140$ & /704 & 1372 & 34780391 & 110138 & 68015 & 35940 \\
\hline & Istra north & $D B W_{30}$ & 149 & $D G W_{30}$ & 1186 & & & & & & 430062 & 1372 & 929 & 601 \\
\hline & Istra west & $D B W_{31}$ & 1222 & $D G W_{31}$ & 8678 & & & & & & 3148926 & 10055 & 6875 & 4536 \\
\hline & Zadar - Unije & $D B W_{32}$ & 1240 & $D G W_{32}$ & 2002 & & & & & & 745835 & 2447 & 2186 & 2071 \\
\hline & Šolta - Kornati & $D B W_{33}$ & 2247 & $D G W_{33}$ & 6170 & & & & & & 2267087 & 7333 & 5753 & 4700 \\
\hline $7 O N F 3$ & Vis - Lastovo & $D B W_{34}$ & 2563 & $D G W_{34}$ & 5755 & $\mathrm{MODF} 3 / 4$ & 2,04 mil./ & $133 /$ & $627 /$ & $1070 /$ & 2124262 & 6902 & 5659 & 4883 \\
\hline ZUNE 3 & Jabuka - Biševo & $D B W_{35}$ & 897 & $D G W_{35}$ & 7135 & MUDE 3/4 & 36 mil. & 1140 & 704 & 372 & 2586786 & 8253 & 5585 & 3614 \\
\hline & \begin{tabular}{|l|} 
Lastovo \\
\end{tabular} & $D B W_{36}$ & 1279 & $D G W_{36}$ & 10175 & & & & & & 3688994 & 11769 & 7965 & 5154 \\
\hline & marginal sea & $D B W_{37}$ & 1739 & $D G W_{37}$ & 13833 & & & & & & 5015461 & 16001 & 10829 & 7007 \\
\hline & Mljet & $D B W_{38}$ & 6407 & $D G W_{38}$ & 10104 & & & & & & 3767970 & 12370 & 11130 & 10614 \\
\hline & Dubrovnik - Kotor & $D B W_{39}$ & 4894 & $D G W_{39}$ & 18450 & & & & & & 6741913 & 21684 & 16057 & 12100 \\
\hline & north Adriatic & $D B W_{40}$ & 24809 & $D G W_{40}$ & 197373 & & & & & & 228840391 & 238054 & 156416 & 82652 \\
\hline ZONE 4 & middle Adriatic & $D B W_{41}$ & 6202 & $D G W_{41}$ & 49335 & MODE 4 & $\begin{array}{c}636 \mathrm{mil} . / 36 \\
\mathrm{mil} .\end{array}$ & $\begin{array}{l}526 / \\
1140\end{array}$ & $\begin{array}{l}704 / \\
704\end{array}$ & $\begin{array}{l}372 / \\
372\end{array}$ & 57205584 & 59505 & 39098 & 20660 \\
\hline & south Adriatic & $D B W_{42}$ & 24706 & $D G W_{42}$ & 196542 & & & & & & 227884073 & 237053 & 155758 & 82304 \\
\hline
\end{tabular}

Results of the evaluation model presented in Fig. 6 indicate that the zone 2 is highly affected with cruise ship traffic. Although this zone is protected from discharge of untreated and inadequately treated black water with Annex IV of MARPOL Convention, the problem is in discharge of gray water, which is not recognized as a pollutant (unless it is mixed with black water). The values in zone 4, or outside the territorial sea of the Republic of Croatia, are large as expected, since there are no requirements for wastewater treatment prior to their discharge. Attention should be paid to the northern Adriatic, which is, due to its small depth, particularly sensitive to all kinds of pollution and in which problem of eutrophication already occurred. Wastewater pollution in zone 3 is shown in more detail in the following chapter. 


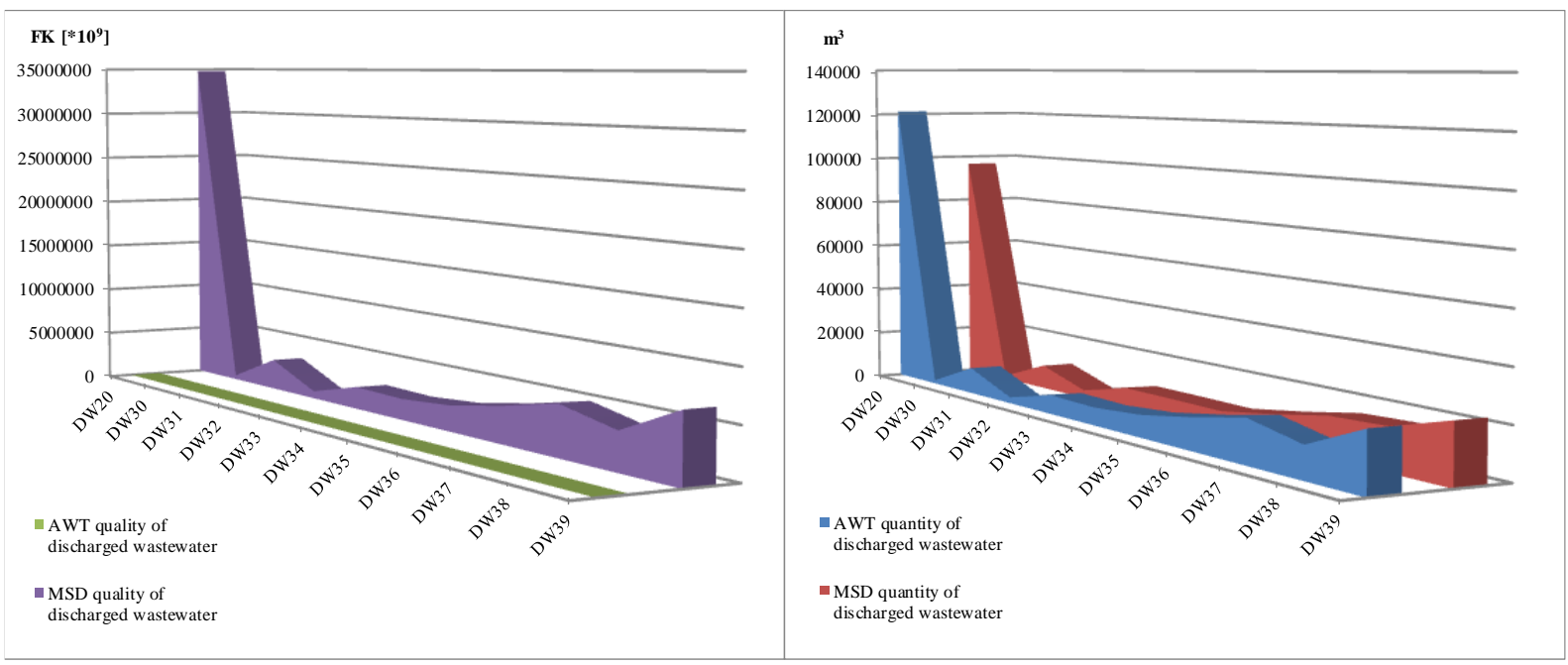

Fig. 6 Case 1 quality and quantity of discharged wastewater in the Adriatic Sea in one-year period considering treatment system and geographic areas of the Republic of Croatia

4.1 Identification of critical sea areas regarding sanitary wastewater pollution from cruise ships

Application of case study data and developed models for evaluation of marine pollution by wastewater from cruise ships in the Adriatic Sea provided quality and quantity of discharged wastewater in fourteen defined geographical areas. Detailed analysis of results for zone 3 allows us to identify critical areas regarding marine pollution of the Adriatic Sea by wastewater. We will consider pollution in two cases:

- Case 1: gray water from ships with MSD is discharged into zone 2 respecting Annex IV of MARPOL Convention.

- Case 2: gray water from ships with MSD is discharged into zone 3, which directly follows zone 2 respecting common practice of cruise ships.

Quantity and quality of discharged wastewater in case 1 is already shown in Fig. 6.

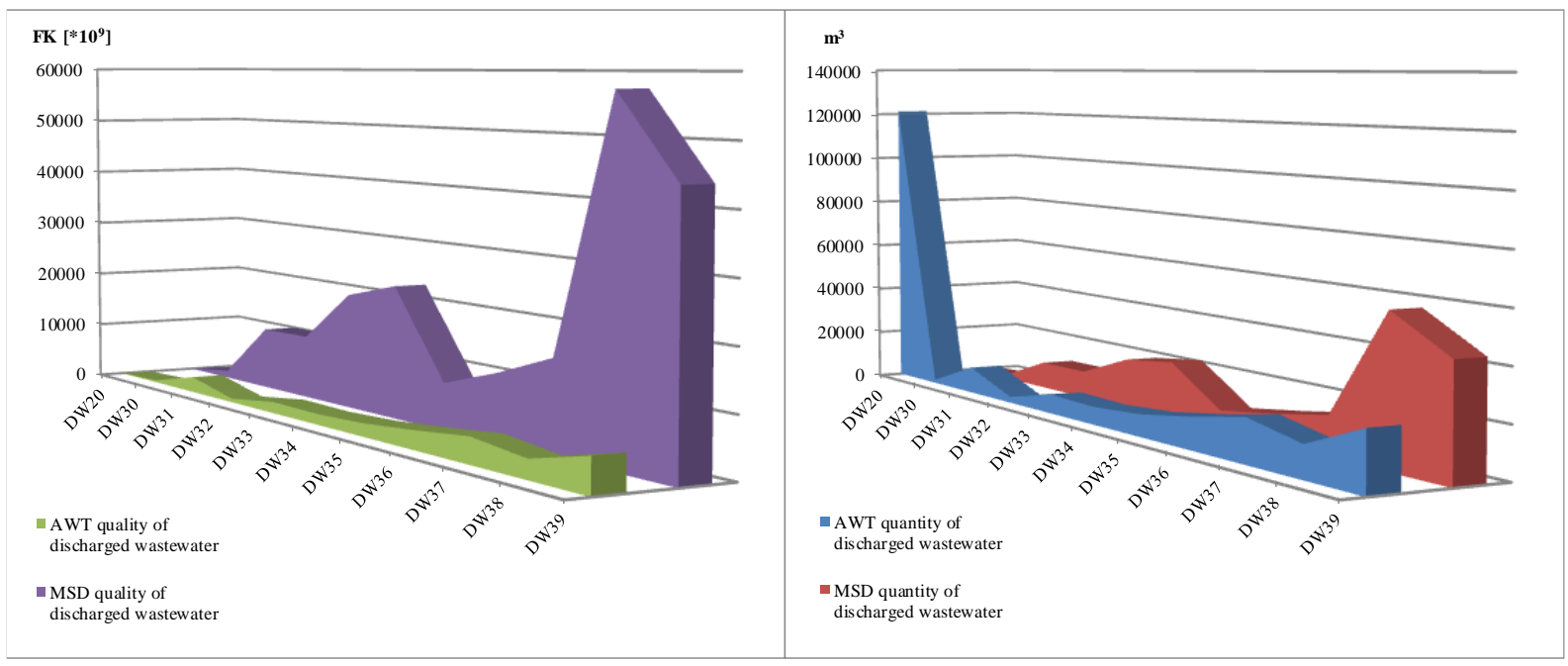

Fig. 7 Case 2 quality and quantity of discharged wastewater in the Adriatic Sea in one-year period considering treatment system and geographical areas of the Republic of Croatia 
For the second case the quantity of gray wastewater generated in zone 2 is divided into zones 3 directly following zone 2 considering movement of the ships on routes. Thus, the quantity of discharged gray water increased in some geographical areas. The largest increase, by as much as $90 \%$, is in the area of Mljet, followed by: Zadar - Unije with an increase of $87 \%$; Vis - Lastovo with 59\%; Dubrovnik - Kotor with 54\% and Šolta - Kornati with an increase of $43 \%$. Fig. 7 graphically shows the quality and quantity of discharged black and gray water in zone 3 of the territorial sea of the Republic of Croatia in case 2.

Critical areas, based on the results of the evaluation model, are:

- Mljet area,

- Dubrovnik - Kotor area and

- area of Lastovo.

In both cases, the largest quantity of wastewater was discharged in the Mljet area which stands out as the most critical area regarding marine pollution by wastewater from cruise ships. It is followed by the Dubrovnik - Kotor area and the area of Lastovo since it combines the contamination of the Lastovo area (DW36) and Vis - Lastovo area (DW34). Marginal sea area is also burdened by discharged wastewater, but is not considered as a critical area because it includes narrow sea area of the territorial sea in the central Adriatic near the state border and the sea area around the island of Palagruža. Because of the distance from the nearest land and the position of the area on high seas, it is concluded that discharged wastewater in this area is not critical to the marine environment.

4.2 Draft guideline for relocation of navigation routes on the larger distance from the Croatian coast

National systems have generally underdeveloped legislative and executive mechanisms to control and manage pollution. Subsequently they are not in a position to respond to the challenges of implementing the six annexes of MARPOL and other relevant conventions [4]. However, pollution can be reduced in different manner by relocation of navigation routes on the larger distance from the coast.

The direct reject of wastewater is one of the major factors of coastal and marine environment degradation, because it is discharged directly into sea with a high concentration of pollutants. Thus, if this discharge is not controlled, the effluent may return to the coastal regions without being sufficiently diluted; so it can contaminate areas for farming, fishing grounds or beaches [17].

So, marine pollution by wastewater from cruise ships has the greatest impact in the coastal area of the sea. Moving away from the mainland reduces the impact of pollution because the wastewater with its quantity and quality is discharged in larger volumes of the sea.

In the most common route in the case study it was noted that most of the ships in navigation between Dubrovnik and Venice tends to sail in close coastal zone (2-5 $\mathrm{M}$ ). Therefore, wastewater is discharged in proximity of the Croatian National Park Mljet and Nature Park Lastovo. Only a small part of the ships chose to relocate the route outside the territorial sea of Croatia. In Fig. 8, the solid line shows the most common navigation route of cruise ships from Dubrovnik and Kotor to the ports of northern Adriatic and vice versa. The dotted lines mark proposed relocated navigation route used by some ships. It is considered necessary to introduce recommended route or even vessel routeing systems for cruise ships that sail between the ports of the eastern coast of the southern Adriatic (Dubrovnik, Kotor, Durres) and the northern Adriatic (Zadar, Koper, Trieste, Venice, Ravenna ...). With the relocated 
routes, cruise ships extend their travel for a negligible $14 \mathrm{M}$ but wastewater load of the protected nature of the Republic of Croatia is reduced to a minimum.

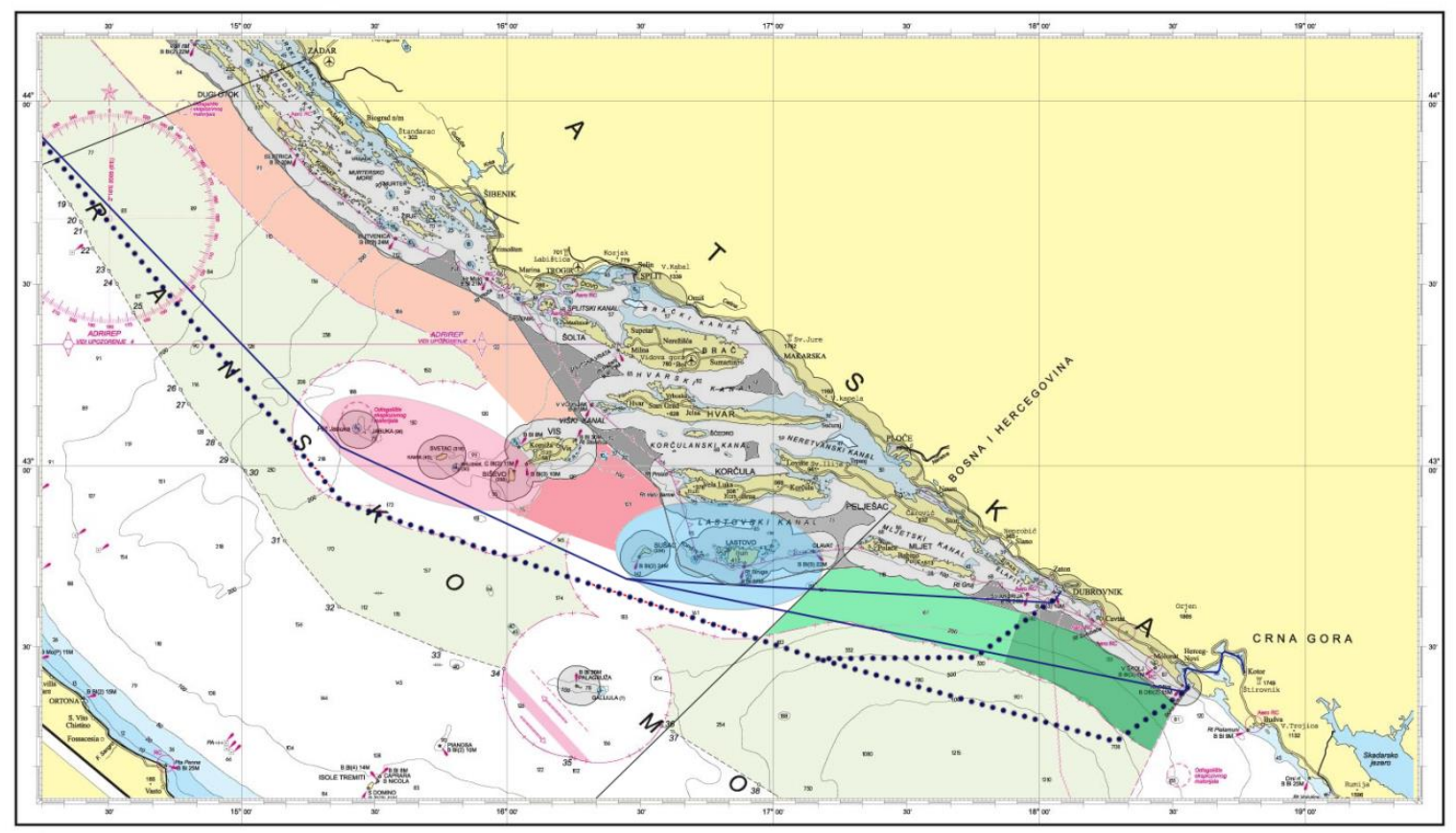

Fig. 8 Relocation of navigation routes on a greater distance from shore

Cruise ships are a special category of ships when choosing the route and speed of navigation on their travels. While merchant ships choose the optimal speed of navigation (regarding fuel prices and freight) and the optimal route (due to the length of time, weather and, of course, navigation restrictions), cruise ships adjust the route and the speed of navigation according to scheduled time of arrival in the next port of call. For these reasons, it is not necessary to choose the shortest possible route between two ports, which enables the realization of the proposed guideline without compromising cruising tourism in the Republic of Croatia.

\section{Conclusion}

Marine pollution from ships is always actual issue because it represents a major threat to the marine environment. This problem is particularly pronounced in closed type of seas like the Adriatic Sea and in countries in which economy is largely based on tourism, therefore, the purity of the sea, such as the Republic of Croatia. Traffic of cruise ships is in continuous growth. New cruise ships are built with constant increase in capacity, which now exceeds 8,000 people. Previous studies on discharge of wastewater from cruise ships deal mainly with quality indicators and treatment technologies of the same. However, there is no model that could evaluate pollution of particular sea areas with wastewater from cruise ships. Therefore, the scientific contribution of this paper is presented evaluation model of marine pollution by wastewater from cruise ships that allows the calculation of quantity and quality of discharged wastewater in a specified geographical areas within a certain period of time in different scenarios. By changing the input parameters and scenarios it is possible to obtain wanted or expected output parameters whose comparison can evaluate the current legal regulations, as well as it can guide us for future legal requirements regarding wastewater pollution.

Using the evaluation model in the scenario that follows the legal requirements of MARPOL's Annex IV critical areas regarding marine pollution by wastewater from cruise ships were identified: Mljet area, Dubrovnik - Kotor area and the area of Lastovo. Evaluation model of marine pollution by wastewater from cruise ships allows us assessment of the level of threat 
to the marine environment. That can guide authorities to future requirements related to the discharge of sanitary wastewater from cruise ships, which will consequently have an impact on the protection of marine environment, and therefore the preservation of tourism as strategic branch of economy and quality of life of coastal populations.

\section{REFERENCES}

[1] Bluewater Network \& Friends of the Earth, 2006, "Ship air pollution", available at: http://www.foe.org/projects/oceans-and-forests/cruise-ships.

[2] Cruise lines international association, 2019, "2019 CLIA State of Cruise Industry Report", available at: http://cruising.org

[3] Cruise Mapper, "Cruise ship passenger capacity“, available at: https://www.cruisemapper.com/wiki/761cruise-ship-passenger-capacity-ratings

[4] Carić, H., 2016, "Challenges and prospects of valuation - cruise ship pollution case", Journal of Cleaner Production, Elsevier, Vol. 111 (B), pp. 487-498. https://doi.org/10.1016/j.jclepro.2015.01.033

[5] Butt, N., 2007, "The impact of cruise ship generated waste on home ports and ports of call: A study of Southampton", Marine Policy, Elsevier, vol. 31(5), pp. 591-598. https://doi.org/10.1016/j.marpol.2007.03.002

[6] Croatian Bureau of Statistics, "Foreign vessels on cruise in the Republic of Croatia", available at: http://www.dzs.hr

[7] United States Environmental Protection Agency, 2008, "Cruise Ship Discharge Assessment Report".

[8] International Maritime Organization (IMO), "International Convention for the Prevention of Pollution from Ships - MARPOL 73/78“،

[9] Perić, T., 2016, "Wastewater pollution from cruise ships in coastal sea area of the Republic of Croatia", Pomorstvo - Scientific Journal of Maritime Research, vol. 2, pp. 160-164. https://doi.org/10.31217/p.30.2.9

[10] Kaldy, J., 2011, "Using a macroalgal $\delta_{15} \mathrm{~N}$ bioassay to detect cruise ship waste water effluent inputs", Marine Pollution Bulletin, Elsevier, Vol. 62 (8), pp. 1762-1771. https://doi.org/10.1016/j.marpolbul.2011.05.023

[11] Perić, T., 2016, "Evaluation model of sanitary wastewater pollution from cruise ships in the Adriatic Sea", doctoral dissertation, Rijeka. https://doi.org/10.7307/ptt.v28i4.2087

[12] Perić, T., Komadina, P., and Račić, N., 2016, "Wastewater pollution from cruise ships in the Adriatic Sea", Promet - Traffic\&Transportation, vol. 28, pp. 425-433, Zagreb. https://doi.org/10.7307/ptt.v28i4.2087

[13] Cohen, G., 2006, "Campaign to safeguard Americas waters: overview of cruise ship facts, criminal history, regulatory status and threats to the environment", Earth island institute.

[14] International Maritime Organization (IMO), Marine Environment Protection Committee, 2006, "Resolution MEPC.159(55): Revised Guidelines on Implementation of Effluent Standards and Performance Tests for Sewage Treatment Plants“.

[15] International Maritime Organization (IMO), Marine Environment Protection Committee, 2011, "Resolution MEPC.200(62): Amendments to the Annex of the Protocol of 1978 Relating to the International Convention for the Prevention of Pollution from Ships, 1973 (Special Area Provisions and the Designation of the Baltic Sea as a Special Area under MARPOL Annex IV)“.

[16] Vidan, P., Vukša, S., Dlabač, T., 2018, "Practice of and attitudes toward familiarisation on board: survey of Croatian and Montenegrin maritime officers", Brodogradnja, Vol. 69 (3), pp. 97-110. https://doi.org/10.21278/brod69306

[17] Ben Hamza, S., Habli, S., Mahjoub Saïd, N., Bournot, H., Le Palec, G., 2015, "Simulation of pollutant dispersion of a free surface flow in coastal water", Ocean Engineering, Elsevier, Vol. 108, pp. 81-97. https://doi.org/10.1016/j.oceaneng.2015.07.059

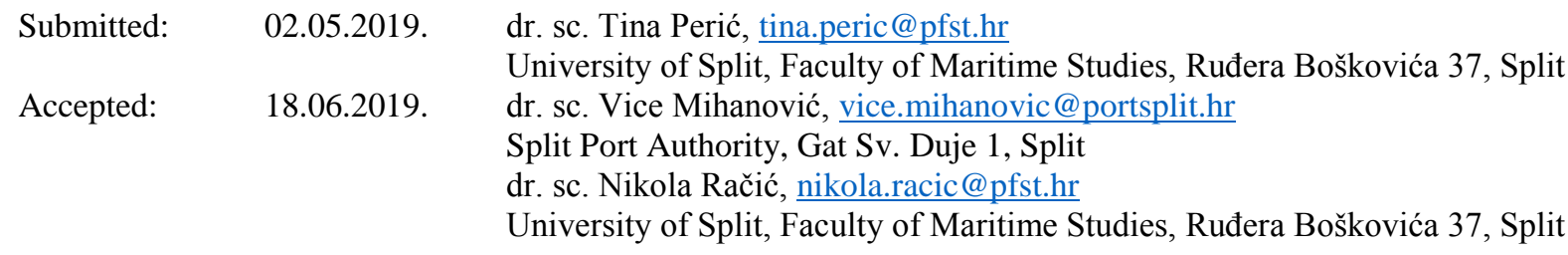

